\title{
Foraging behaviour of the Scale-throated Hermit Phaethornis eurynome Lesson, 1832 (Aves, Trochilidae) in Vriesea incurvata Gaudich (Bromeliaceae)
}

\author{
Silva, BG. ${ }^{a *}$ and Piratelli, AJ. ${ }^{b}$ \\ aPrograma de Pós-graduação em Diversidade Biológica e Conservação, Universidade Federal de São Carlos, \\ Campus Sorocaba. Rod. João Leme dos Santos, Km 110, Itinga, CEP 18052-780, Sorocaba, SP, Brazil

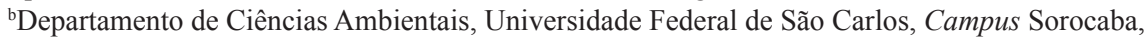 \\ Rod. João Leme dos Santos, Km 110, Itinga, CEP 18052-780, Sorocaba, SP, Brazil \\ *e-mail: bgsilvab@gmail.com
}

Received July 31, 2012 - Accepted March 22, 2013 - Distributed May 31, 2014

(With 2 figures)

\begin{abstract}
In this study we tested for density-dependent relationships between visitation rates of the Scale-throated Hermit (Phaethornis eurynome) and the plant density and flower number of the bromeliad Vriesea incurvata, by comparing plots with varying densities of this bromeliad. Eight $100 \mathrm{~m}^{2}$ plots were established at least $200 \mathrm{~m}$ from each other; four plots contained 10-15 individuals of $V$. incurvata each, whereas the other four contained 4-5 individuals each. The visitors, number of visits, behaviour (nectar thief or potential pollinator) and the height of foraging were recorded during focal observations on the plants. The number of visits of $P$. eurynome varied according to the local density of $V$. incurvata, showing that the heterogeneous distribution of this bromeliad species may promote adjustments in the pollinator populations, through resource variation at a local scale.
\end{abstract}

Keywords: Atlantic forest; Bromeliaceae; foraging behaviour; Phaethornis eurynome

\section{Comportamento alimentar de Phaethornis eurynome Lesson, 1832 (Aves, Trochilidae) em Vriesea incurvata Gaudich (Bromeliaceae)}

\section{Resumo}

Neste estudo foram testadas as relações entre taxas de visitação de Phaethornis eurynome e a densidade e o número de flores de Vriesea incurvata, comparando-se parcelas com diferentes densidades desta bromélia. Oito parcelas de $100 \mathrm{~m}^{2}$ foram estabelecidas a pelo menos $200 \mathrm{~m}$ uma da outra; quatro parcelas continham de 10 a 15 indivíduos de V. incurvata cada, enquanto as outras quatro continham de 4 a 5 indivíduos cada. Os visitantes, o número de visitas, o comportamento (pilhador ou potencial polinizador) e altura de forrageamento foram registrados em observações focais das plantas. O número de visitas por $P$. eurynome variou conforme a densidade de $V$. incurvata na área, demonstrando que a distribuição heterogênea desta bromélia pode promover ajustes populacionais por parte dos polinizadores, através da variação da oferta de recursos em uma escala local.

Palavras-chave: Mata Atlântica; Bromeliaceae; comportamento alimentar; Phaethornis eurynome

\section{Introduction}

Phenological patterns in plant communities are important tools for understanding plant-animal interactions, as they provide crucial information on plant reproduction and the temporal and spatial distribution of food resources in the environment (Talora and Morellato, 2000). Abundance and community bird composition may vary in association with spatial and temporal habitat variation (Levey, 1988; Loiselle and Blake, 1991), such as the spatial distribution of resources (Loiselle and Blake, 1993) and temporal changes in vegetation as part of succession (Johns, 1991).

Birds are the most common pollinators in the Bromeliaceae (Sazima et al., 1996; Buzato et al., 2000).
Key features of bird-pollinated bromeliads include deep-red floral bracts, yellowish tubular flowers, abundant production of dilute nectar, and diurnal anthesis (Sazima et al., 1996). In the Atlantic forest, bromeliads account for about 30 percent of food resources used by hummingbirds (Apodiformes; Trochilidae) (Sazima et al., 1995; 1996). These birds are restricted to the Americas and are mostly Neotropical in distribution, comprising around 100 genera and 300 species (Tiebout, 1993). Thirty-eight genera and 86 species occur in Brazil, with 30 species known or expected to occur in the southeastern Atlantic forest (Grantsau, 1989). 
Pollination rates of a given plant species often depend on the amount or quality of floral visitors. Nectarivores may prefer to forage in larger clumps of flowering plants to maximize energy intake (Heinrich and Raven, 1972; Pyke, 1981), and this can affect their abundance in a given area and the frequency of their visits to plant species there. In this study we tested for density-dependent relationships between number of contacts and visits of nectarivores and the plant density and flower number of a bromeliad species. The specific objectives were: (1) to estimate visitation rate of the Scale-throated Hermit (Phaethornis eurynome Lesson, 1832, Aves, Trochilidae) and how they vary with varying densities of the bromeliad Vriesea incurvata Gaudich, and (2) to compare the visitation frequency of the Scale-throated Hermit with $V$. incurvata density and number of open flowers.

\section{Material and Methods}

\subsection{Study species}

Vriesea incurvata Gaudich is an herbaceous, acaulescent, epiphytic bromeliad, reaching $50 \mathrm{~cm}$ in height. It has ten or more smooth, dark green leaves without spines and arranged in a rosette-forming receptacle where water accumulates. The species prefers environments with diffuse light and is typically found on the lower or middle portions of host trees (Reitz 1983) (Figure 1A). The sparse roots measure up to $10-20 \mathrm{~cm}$ long and the inflorescence is dense, submultifloral, and can be up to $30 \mathrm{~cm}$ tall and $7.5 \mathrm{~cm}$ wide (Figure 1B). Only one flower opens per inflorescence per day, and flowers possess various features that are typical of bird pollination: red bracts, yellow tubular flowers, a mean nectar volume of $25.5 \pm 21.8(\mathrm{SD}) \mathrm{ml}$, and a mean nectar concentration of $15 \%(\mathrm{SD}=11 \%, \mathrm{~N}=30)$ (Rocca de Andrade, 2006).

The Scale-throated Hermit typically inhabits the understory of the Atlantic forest where, like other hummingbirds, feeds on nectar and arthropods (Buzato et al., 2000). It visits open $V$. incurvata flowers and appears to be a legitimate pollinator (Figure 1B), but it also sometimes acts as a nectar thief by reaching between flower bracts to collect nectar without removing or depositing pollen.

\subsection{Study site}

The study was carried out between February and May 2011 at Carlos Botelho State Park (between 246'55" and $24^{\circ} 14^{\prime} 41^{\prime \prime} \mathrm{S}$, and $47^{\circ} 47^{\prime} 18^{\prime \prime}$ and $48^{\circ} 07^{\prime} 17^{\prime \prime} \mathrm{W}$ ) with $37,644.36$ ha of lowland tropical rain forest $(0-50 \mathrm{~m}$ elevation), submontane tropical rain forest $(51-500 \mathrm{~m})$ and montane tropical rain forest (501-1500 m), and some farmland, pasture, swamps, and pine, banana, and eucalyptus plantations (Ferraz and Varjabedian, 1999; Kronka et al., 2005). Climate in the submontane and lowland is hot and wet with no dry season, and wet temperate with no dry season in the montane areas. Average annual temperatures vary from $18^{\circ}-20^{\circ} \mathrm{C}$ and annual rainfall between $1500-2200 \mathrm{~mm}$ (Ferraz and Varjabedian, 1999).

To examine the effect of $V$. incurvata density on visitation of the Scale-throated Hermit, eight $100 \mathrm{~m}^{2}$ plots were set up at least $200 \mathrm{~m}$ from each other. Four plots contained 10-15 individuals of $V$. incurvata each (hereafter referred to as high-density plots), whereas the other contained 4-5 individuals each (low-density plots). All plots were in mature montane rain forest at approximately 800 m elevation.

Vriesea incurvata individuals were marked as they flowered in order to conduct focal observations (each lasting 60-240 $\mathrm{min}$ ) between 07:30 $\mathrm{h}$ and 12:00 h. Visitors, number of contacts, number of visits, behaviour (nectar thief or potential pollinator) and height of foraging were recorded. A contact was considered when a given hummingbird species was detected inside the plots. To test for hummingbird preferences for a given vertical stratum, we visually estimated the height above the ground of all $\mathrm{V}$. incurvata individuals in the plots.

\subsection{Statistical analyses}

We compared the frequency of visitation of the Scalethroated Hermit between high-density and low-density plots, and the average height of $V$. incurvata individuals and the mean foraging height of the Scale-throated Hermit, using $t$-tests. We tested for relations between frequency of visits of the Scale-throated Hermit with the density and availability of $V$. incurvata flowers using regression analysis. The free statistical software $R$ was employed for
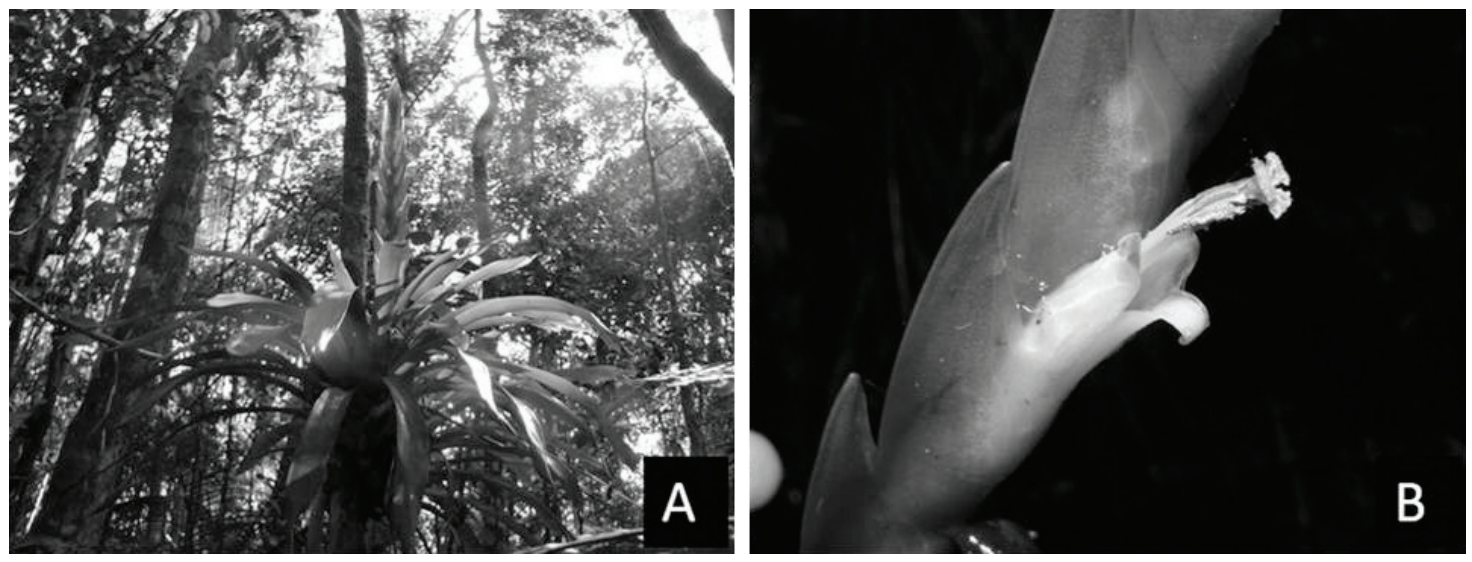

Figure 1. (A) The bromeliad Vriesea incurvata Gaudich in a natural environment. (B) Open flower of V. incurvata. 
all analyses (R Development Core Team, 2008). Values reported in the results are means \pm SD.

\section{Results}

A total of 63 flowering individuals of $V$. incurvata were studied between February and May. Flowering began in February, and was most intense between March and April. One peduncle per individual plant was observed (Figure 1A and B). We chose focal observations of plants so that while under observation, no other plants in the plots flowered, thereby reducing the possible influence of other nectar sources in the study area.

The Scale-throated Hermit was noted four times in lowdensity plots and 18 times in high-density plots (Table 1). Number of contacts was significantly greater in the highdensity plots $\left(t_{6}=1.94, \mathrm{P}=0.05\right)$. On two occasions we also observed Thalurania glaucopis foraging in the plots, but these did not visit the flowers. One sighting occurred in one low-density plot and the other in one high-density plot.
Bromeliad height was the same in both low-density and high-density plots ( $t=0.14, P=0.89)$, but the Scalethroated Hermit foraged at greater height in high-density plots $\left(t_{22}=3.78, P=0.001\right)$. In both areas, the mean foraging height of the Scale-throated Hermit was lower than the mean bromeliad height, suggesting that the lowest bromeliads were the most visited (Table 1).

The number of contacts of the Scale-throated Hermit was positively related with $V$. incurvata density $\left(R_{1,6}^{2}=0.48\right.$, $P=0.03)$, variation in bromeliad density explained 48 percent of variation in the Scale-throated Hermit contacts (Figure 2A). The number of the Scale-throated Hermit visits to flowers, regardless of foraging behaviour (nectar thief or pollinator) also increased with increasing $V$. incurvata $\operatorname{density}\left(R_{1,6}^{2}=0.55, P=0.02\right)$. (Figure $2 \mathrm{~B}$ ). There was a marginal positive relationship between the number of open flowers and the number of visits in all plots $\left(R_{1,6}^{2}=0.41\right.$, $P=0.051$ ) (Figure 2C).

Table 1. Vertical distribution of individuals of Vriesea incurvata, number of open flowers, number of visits, foraging behaviour and height of the Scale-throated Hermit (Phaethornis eurynome) in eight plots sampled at Carlos Botelho State Park, São Paulo state, Brazil.

\begin{tabular}{|c|c|c|c|c|c|c|c|c|c|}
\hline \multirow[b]{2}{*}{ Plots } & \multirow[b]{2}{*}{$\begin{array}{c}\text { V. incurvata } \\
\text { (N) }\end{array}$} & \multirow{2}{*}{$\begin{array}{c}\text { Height } \\
\text { above the } \\
\text { ground (m) } \\
\text { Mean and } \\
\text { standard } \\
\text { deviation }\end{array}$} & \multirow[b]{2}{*}{$\begin{array}{c}\text { Open } \\
\text { flowers }\end{array}$} & \multicolumn{4}{|c|}{ Behaviour and number of visits $(\mathrm{N})$} & \multirow[b]{2}{*}{$\begin{array}{c}\text { Mean } \\
\text { foraging } \\
\text { height }(m)\end{array}$} & \multirow[b]{2}{*}{$\begin{array}{c}\text { Total } \\
\text { observation } \\
\text { time (min.) }\end{array}$} \\
\hline & & & & $\begin{array}{c}\text { Number } \\
\text { of } \\
\text { contacts }\end{array}$ & $\begin{array}{c}\text { Nectar } \\
\text { thief }\end{array}$ & Pollinator & Total & & \\
\hline A & 4 & $3.12 \pm 0.62$ & $1(2.5)^{\mathrm{a}}$ & 0 & 0 & $1(1)^{b}$ & $1(1)^{b}$ & 2.5 & 180 \\
\hline $\mathrm{B}$ & 5 & $3.3 \pm 2.72$ & 0 & 2 & $1(1)^{\mathrm{b}}$ & 0 & $1(1)$ & 1 & 240 \\
\hline $\mathrm{C}$ & 4 & $3.62 \pm 0.75$ & 0 & 0 & 0 & 0 & 0 & - & 180 \\
\hline $\mathrm{D}$ & 4 & $2.87 \pm 3.11$ & $1(1)$ & 0 & 0 & 0 & 0 & - & 300 \\
\hline $\mathrm{E}$ & 10 & $2.48 \pm 1.49$ & $1(2)$ & 2 & $1(1)$ & $2(2)$ & $3(3)$ & 2.5 & 200 \\
\hline $\mathrm{F}$ & 15 & $3.48 \pm 2.21$ & $3(2.76)$ & 3 & $2(4)$ & $3(11)$ & $5(15)$ & 2.57 & 300 \\
\hline $\mathrm{G}$ & 10 & $3.02 \pm 1.21$ & $1(3)$ & 0 & $3(5)$ & $2(2)$ & $5(7)$ & 2.46 & 180 \\
\hline $\mathrm{H}$ & 11 & $3.48 \pm 1.19$ & $2(3.55)$ & 0 & 0 & 0 & 0 & & 180 \\
\hline
\end{tabular}

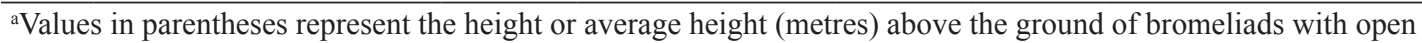
flowers. ${ }^{b}$ Values in parentheses refer to the total number of visits by individuals to the inflorescence.
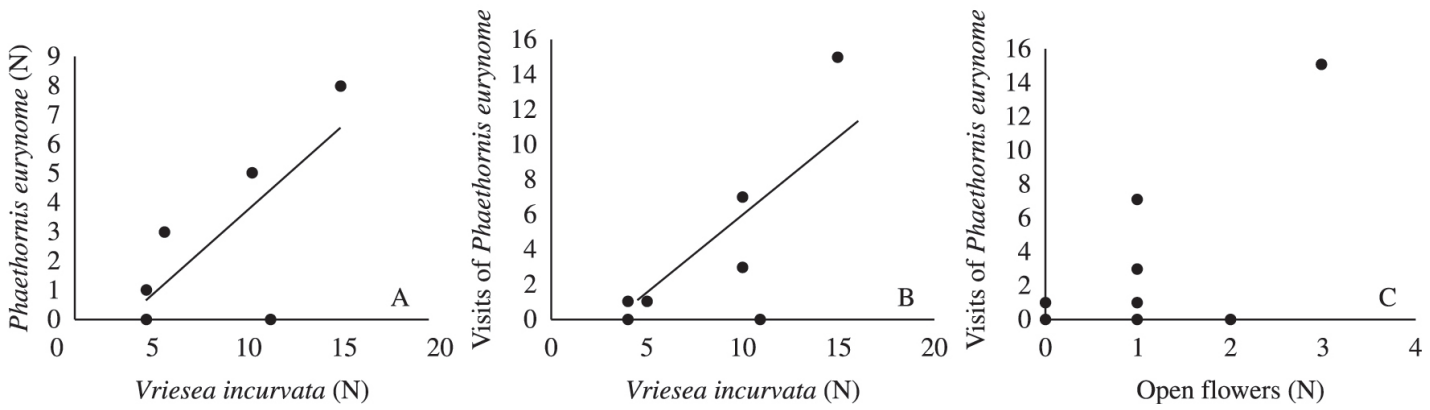

Figure 2. (A) Simple linear regression analysis between the number of $V$. incurvata individuals and the number of contacts of the Scale-throated Hermit (Phaethornis eurynome) observed in different plots $\left(R^{2}=0.47, P=0.033\right.$ ). (B) Simple linear regression analysis between the number of $V$. incurvata individuals and the number of the Scale-throated Hermit visits (including pollinators and robbers) observed in different plots $\left(R^{2}=0.78, P=0.02\right)$. (C) Analysis of linear regression between the number of open $V$. incurvata flowers and the number of the Scale-throated Hermit visits (including pollinators and robbers) observed in the different plots $\left(R^{2}=0.70, P=0.051\right)$. 


\section{Discussion}

Although nectarivores such as the Scale-throated Hermit are highly mobile foragers (Kunin, 1997), small-scale variation in habitat features such as the spatial distribution of food resources (Loiselle and Blake, 1991) seems to strongly affect their foraging patterns. The difference in foraging height between the low-density and high-density plots may be due to the presence of open flowers at different heights in those areas. In low-density plots open flowers occurred mostly in the lower bromeliads, while in highdensity plots they mostly occurred in the highest bromeliads, which may have preferentially attracted nectarivores to that stratum. The weak relation between number of open flowers and number of visits is possibly due to the fact that the Scale-throated Hermit may behave both as nectar thief and pollinator (Kaehler et al., 2005), and is therefore not dependent on open flowers.

The heterogeneous distribution of bromeliads in the study site, with variations in both plant density and pollinator resources at the local scale (Feinsinger et al., 1991), resulted in a possible adjustment of the population as the number of visits to flowers depending on the number of individuals of $V$. incurvata in the area. It is advantageous for foragers to make more frequent feeding visits to sites with abundant floral resources, where they can maximise energy intake while minimising foraging effort (Pyke, 1981; Mitchell et al., 2004). Our data thus show that varying in spatial distribution of this bromeliad species may promote adjustments in the pollinator populations, in response to availability of food resources.

Acknowledgements - We thank Alexander Vicente Christianini and Alexander Zamorano Antunes for suggestions that improved the study, and the staff of Carlos Botelho State Park for their support with this research.

\section{References}

BUZATO, S., SAZIMA, M. and SAZIMA, I., 2000. Hummingbirdpollinated floras at three Atlantic forest sites. Biotropica, vol. 32, no. 4b, p. 824-841. http://dx.doi.org/10.1111/j.1744-7429.2000. tb00621.x.

FEINSINGER, P., TIEBOUT III, HM. and YOUNG, BE., 1991. Do tropical bird-pollinated plants exhibit density-dependent interaction? Field experiments. Ecology, vol. 72, no. 6, p. 19531963. http://dx.doi.org/10.2307/1941550.

FERRAZ, LPM. and VARJABEDIAN, R., 1999. Evolução histórica da implantação e sintese das informações disponiveis sobre o Parque Estadual Carlos Botelho. São Paulo: SMA/CINP/ IF/DRPE/PECB. 95 p.

GRANTSAU, R.,1989. Os beija-flores do Brasil. Rio de Janeiro: Expressão e Cultura. 234 p.

HEINRICH, B. and RAVEN, PH., 1972. Energetics and pollination ecology. Science, vol. 176, no. 4035, p. 597-602. PMid: 17778157. http://dx.doi.org/10.1126/science.176.4035.597.

JOHNS, AD., 1991. Responses of Amazonian rain forest birds to habitat modification. Journal of Tropical Ecology, vol. 7, no. 4, p. 417-437. http://dx.doi.org/10.1017/S0266467400005812.
KAEHLER, M., VARASSIN, IG. and GOLDENBERG, R., 2005. Polinização em uma comunidade de bromélias em Floresta Atlântica alto-montana no Estado do Paraná, Brasil. Revista Brasileira de Botânica, vol. 28, no. 2, p. 219-228.

KRONKA, FJN., NALON, MAC., MATSUKUMA, K., KANASHIRO, MM., YWANE, MSS., PAVÃO, M., DURIGAN, G., LIMA, LMPR., GUILLAUMON, JRJ., BAITELLO, B., BORGO, SC., MANETTI, LA., BARRADAS, AMF., FUKUDA, JC., SHIDA, CN., MONTEIRO, CHB., PONTINHA, AAS., ANDRADE, GG., BARBOSA, O. and SOARES, AP.,2005. Inventário florestal da vegetação natural do Estado de São Paulo. São Paulo: Secretaria do Meio Ambiente/Instituto Floresta1/Imprensa Oficial. p. 200.

KUNIN, WE., 1997. Population size and density effects in pollination: pollinator foraging and plant reproductive success in experimental arrays of Brassica kaber. Journal of Ecology, vol. 85, no. 2, p. 225-234. http://dx.doi.org/10.2307/2960653.

LEVEY, DJ., 1988. Spatial and temporal variation in Costa Rica fruit and fruit-eating bird abundance. Ecological Monographs, vol. 58, no. 4, p. 251-269. http://dx.doi.org/10.2307/1942539.

LOISELLE, BA. and BLAKE, JG., 1991. Temporal variation in birds and fruits along an elevation gradient in Costa Rica. Ecology, vol. 72, no. 1, p. 180-193. http://dx.doi.org/10.2307/1938913.

LOISELLE, BA. and BLAKE, JG.,1993. Spatial distribution of understory fruit-eating birds and fruiting plants in a neotropical lowland fores. In FLEMMING, T.H. and ESTRADA, A. (Eds.). Frugivory and seed dispersal: ecological and evolutionary aspects. Dordrecht: Kluwer Academic. p. 177-189.

MITCHELL, RJ., KARRON, JD., HOLMQUIST, V. and BELL, JM., 2004. The influence of Mimulus ringens floral display size on pollinator visitation patterns. Functional Ecology, vol. 18, no. 1, p. 116-124. http://dx.doi.org/10.1111/j.1365-2435.2004.00812.x.

PYKE, GH.,1981. Optimal foraging in nectar-feeding animals and coevolution with their plants. In KAMIL, A.C. and SARGENT, TD. (Eds.). Foraging behaviour: ecological, ethological and psychological approaches. New York: Garland STPM Press. p. 19-38.

R Development Core Team,2008. $R$ : a language and environment for statistical computing. Vienna: R Foundation for Statistical Computing. Available from: $<$ http://www.R-project.org $>$.

REITZ, R.,1983. Bromeliáceas e a malária: bromélia endêmica. In REITZ, R. (Ed.). Flora ilustrada catarinense. Itajaí: Herbário Barbosa Rodrigues. p. 59

ROCCA DE ANDRADE, MA.,2006. Recurso floral para aves em uma comunidade de Mata Atlântica de encosta: sazonalidade e distribuição vertical. Campinas: Universidade Estadual de Campinas. Tese de Doutorado em Biologia Vegetal.

SAZIMA, I., BUZATO, S. and SAZIMA, M., 1995. The sawbilled hermit Ramphodon naevius and its flowers in southeastern Brazil. Journal fur Ornithologie, vol. 136, no. 2, p. 195-206. http://dx.doi.org/10.1007/BF01651241.

SAZIMA, I., BUZATO, S. and SAZIMA, M., 1996. An assemblage of hummingbird-pollinated flowers in a montane forest in Southeastern Brazil. Botanica Acta, vol. 109, no. 2, p. 149-160. http://dx.doi.org/10.1111/j.1438-8677.1996.tb00555.x.

TALORA, DC. and MORELLATO, LPC., 2000. Fenologia de espécies arbóreas em floresta de planície litorânea do sudeste do Brasil. Revista Brasileira de Botânica, vol. 23, no. 1, p. 13-26.

TIEBOUT, HM., 1993. Mechanisms of competition in tropical hummingbirds: metabolic costs for losers and winners. Ecology, vol. 74, no. 2, p. 405-418. http://dx.doi.org/10.2307/1939302. 